International Research Journal of Engineering, IT \& Scientific Research
Available online at https://sloap.org/journals/index.php/irjeis/
Vol. 5 No. 5, September 2019, pages: 16 25
ISSN: 2454-2261
https://doi.org/10.21744/irjeis.v5n5.726

\title{
Teaching Strategies and Technology Integration in Developing Blended Learning of Applied Mathematics Subject
}

\author{
I Gede Made Karma ${ }^{\text {a }}$ \\ I Ketut Darma ${ }^{\text {b }}$ \\ I Made Anom Santiana ${ }^{c}$
}

Article history:

Received: 18 January 2019

Accepted: 31 July 2019

Published: 02 September 2019

\section{Keywords:}

applied mathematics;

blended learning;

curriculum design;

learning strategies;

technology integration;

\begin{abstract}
Applied Mathematics is a basic skill that determines the success of students in pursuing their education in the Department of Mechanical Engineering. Besides having to understand concepts and be able to solve cases according to the topics taught, students are also required to be able to solve mathematical engineering problems in the application of mechanical engineering. This makes it a difficult subject for the majority of students. This difficulty is overcome by applying blended learning. This is done by integrating curriculum design with strategy and use of learning technology so that innovation and teaching excellence are formed to support the learning process of students. Learning strategies that can be applied include explanations of concepts, problem-based learning, problem-solving and case discussions. This learning strategy is supported by multimedia technology and internet-based, namely video tutorials, discussion of material and examples of online-based cases and online discussion forums. The process of face-to-face learning in class is still being carried out. The key to the success of this learning lies in the ability to create interactions between students and fellow students, with teachers, with the community, with the material with the use of existing technology.
\end{abstract}

2454-2261 ${ }^{\circledR}$ Copyright 2019. The Author. This is an open-access article under the CC BY-SA license (https://creativecommons.org/licenses/by-sa/4.0/) All rights reserved.

\section{Author correspondence:}

I Gede Made Karma,

Accounting Department

Politeknik Negeri Bali, Badung, Indonesia.

Email address: igmkarma@pnb.ac.id

a Politeknik Negeri Bali, Badung, Indonesia

${ }^{\mathrm{b}}$ Politeknik Negeri Bali, Badung, Indonesia

${ }^{c}$ Politeknik Negeri Bali, Badung, Indonesia 


\section{Introduction}

The existence of information technology has facilitated the teaching process which has created a new space which is better known as e-learning (Ellis \& Goodyear, 2013; Sife et al., 2007). E-learning is a learning media that utilizes the use of computers, or electronic equipment such as smartphones (Altbach \& Knight, 2007; Laurillard, 2005). In the education process, the application of e-learning can be focused on the needs of students and not on the needs of instructors, or educational institutions (Pande et al., 2016; Subramanian, 2016; Ginaya et al., 2018). Unfortunately, e-learning only focuses on the presentation of physical classroom-based learning content via the Internet and tends to be a repetition or compilation of an online version of a class-based course (Singh, 2003). Elearning focuses more on incorporating new technological features and exploring software standards than on efforts to find solutions to psych pedagogical problems (Alonso et al., 2005b).

Various approaches, models and frameworks that can be applied in analyzing, designing, developing, implementing, and evaluating the learning process. Another thing that should also be noted is related to efforts to increase participation and motivation, which ultimately relates to student success (Czerkawski \& Lyman, 2016). More and more educational institutions are using technology to increase student participation and flexibility in learning. Integrating face-to-face classes with the use of technology, such as voice / visual conferencing and the virtual world, can influence student learning activities and outcomes (Bower et al., 2015).

By adopting web-based education and learning through learning management systems (LMS), it is possible for universities to open courses on-campus or off-campus (Samarawickrema \& Stacey, 2007). The use of LMS has a significant effect on student satisfaction (Ozkan \& Koseler, 2009). Distance education, which is part of distributed learning, focuses on students who are separated by time and space from their friends and instructors. Distributed learning provides greater flexibility and eliminates time as a barrier (Rennie \& Morrison, 2013), and is best suited to accommodate the need for learning (Sun et al., 2008). The integrated learning model by utilizing e-learning that is applied in the world of education turns out to have a positive impact on increasing student motivation which at the same time has a good impact on improving learning outcomes (Alkhalaf et al., 2012; Tambunan et al., 2018).

Those who have grown up with interactive technology are not always comfortable with the approach of transmitting information from lectures. Students expect relevant and interesting learning experiences (Garrison \& Vaughan, 2012). It is not surprising that lately, students are more receptive to learning material in the form of podcasts (digital multimedia files available on the Internet, which can be downloaded and then played on media players, either on computers or smartphones) than lectures or traditional textbooks (Evans, 2008).

To make e-learning more effective, it must be combined with other forms of learning such as face-to-face learning. This combination leads to a new methodology called blended learning. This mixed learning has proven to be the most effective learning system (Azizan, 2010; Mahayukti et al., 2017). There is increasing interest in the concept of blended learning as evidenced by more books, journal articles, and trade magazine articles that directly address issues related to blended learning (Graham, 2011; Widana et al., 2018). Blended learning refers to the various possibilities presented by combining the Internet and digital media with an established classroom form that requires the physical presence of teachers and students (Friesen, 2012). Literally, we can translate it as "mixed learning" and the novelty of the term is not in accordance with the tradition of practice it contains (Bartolomé, 2004). It is

important to balance online access to human knowledge and face-to-face interaction on the development of blended learning (Graham \& Dziuban, 2008; Suweken et al., 2017).

\section{Materials and Methods}

There is increasing use of blended learning, which is the convergence between online and traditional teaching which has become a trend in academics (Cohen, 1998; Sanchez \& Garcia, 2019). Blended learning is learning based on various combinations of face-to-face learning, learning via the Internet, and learning supported by other technologies, which aim to create the most efficient learning environment (Hoic-Bozic et al., 2009). Blended learning offers ideas and practical suggestions on how to use technology to improve and support the learning process (Tyley, 2012). Blended learning also combines other elements such as online and traditional learning environments, technology and media for learning content delivery, different teaching and learning methods (both online and traditional), group and individual learning activities, and synchronous and asynchronous interactions (Alonso et al., 2005a; Thorne, 2003). The aim is to choose a mix that will greatly motivate students, and assist them in successfully

Karma, I. G. M., Darma, I. K., \& Santiana, I. M. A. (2019). Teaching strategies and technology integration in developing blended learning of applied mathematics subject. International Research Journal of Engineering, IT \& Scientific Research, 5(5), 16-25. https://doi.org/10.21744/irjeis.v5n5.726 
mastering the course (Johnson \& Aragon, 2003). There was a statistically significant improvement in student performance under the blended learning approach (Kiviniemi, 2014). Improved performance, attendance, and satisfaction with learning outcomes due to the implementation of blended learning show that this new learning model is very suitable to be applied (Stockwell et al., 2015).

Mastery in computer operations, expectations for results, system functionality, learning materials, interactions with material providers and other participants, and the learning climate are the main determinants of learning satisfaction. This can be used as a guide in planning and implementing blended learning (Wu et al., 2010). The framework for adopting blended learning as an institution includes 3 (three) stages, namely exploration, adoption, and implementation (Porter et al., 2014). This framework also identifies the main strategies, structures, and support issues that can be addressed by the university at each stage.

In the implementation of blended learning, there are 3 (three) components that need to be considered. These three components are curriculum design, teaching strategies and integration of technology application (Garrison \& Vaughan, 2012). Consideration and integration of these three components are expected to be able to get the advantages of teaching and innovation in supporting student learning, as shown in Figure 1.

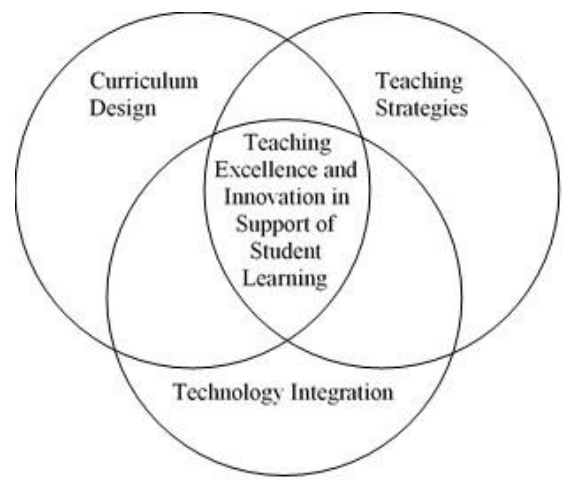

Figure 1. Integrating three components in blended learning implementation

The application of blended learning should begin by considering various construction of blended learning that enables learning that is centered on lecturers or students. Furthermore, the learning design is directed centered on students for certain topic units. After being evaluated, this design is then developed into a mixed methodology that emphasizes more on the activeness and independence of students, so that the success of learning is the responsibility of students (de George-Walker \& Keeffe, 2010). To succeed in the implementation of a mixed learning program, alignment of institutional, faculty and student goals are needed. Reliable and strong infrastructure must be in place to support students and teaching staff, and ongoing evaluations need to be carried out to determine the impact of applying blended learning (Moskal et al., 2013; Mahendra, 2016).

\section{Results and Discussions}

Based on the education curriculum, each lesson is required to have 2 (two) competencies, namely core competencies, and basic competencies. Core competence is the level of ability to achieve graduate competency standards that must be possessed by a student, while basic competence is the ability and minimum learning material that must be achieved. Core competencies include 4 (four) competencies, namely (1) spiritual attitude competencies, (2) social attitudes, (3) knowledge, and (4) skills. The competency is achieved through curricular, co-curricular and/or extracurricular learning processes. On the other hand, the determination of basic competencies refers to core competencies.

The competence of spiritual attitude and social attitude is achieved through indirect learning, that is the example, habituation, and school culture by paying attention to the characteristics of the subjects, as well as the needs and conditions of students. Growth and development of attitude competencies are carried out throughout the learning process and can be used as teacher considerations in developing the character of learners further.

Knowledge competence emphasizes the ability to understand and apply knowledge (factual, conceptual, and procedural) based on curiosity in science, technology, art, culture related to visible phenomena and events. Skills competence is related to the ability to process, reason, and serve in the realm of concrete and abstract domains 
related to the development of what they learn in school independently, to act effectively and creatively, and to be able to use methods according to scientific principles.

Mathematics lessons, in general, are subjects that are not liked and feared by students. This is because this lesson is not easy and difficult to learn. For students to get the understanding as expected, it is not uncommon for lecturers to explain a topic and discuss a case repeatedly. On the other hand, mathematics is a basic lesson, which must be mastered by students to support other subjects. Besides having to understand various concepts, students are also required to be skilled in solving various cases and of course must be able to apply or implement them in the problems they face.

The process of face-to-face learning in class, for some students, is boring and considered difficult to follow. Although often used for teaching concepts or understanding, it is often considered less effective. Sometimes, experienced lecturers are able to arouse students' active roles during class time. Time constraints sometimes also become obstacles, so some material is not delivered, or even the level of student achievement is not as expected. The way out taken by the lecturer is to give assignments, both individual or group assignments. For students who already understand when taught, certainly not a problem. A big problem for those who have not or do not understand the material that has been taught. Therefore, it is necessary to find a solution to this problem.

Every person has a different way and time of the study. Some like to read, hear or watch simulations or movements. Some immediately understood and understood even though it was only explained once. Some have to be explained many times, but it's still difficult to understand. Some of them explained that they understood, but there were also steps that needed to be shown. In essence, everyone has a different approach. For this reason, various approaches and methods need to be prepared, so that the expected goals can be achieved.

One approach that can be applied to overcome various problems and difficulties in this learning process, and at the same time improve the achievement of learning outcomes is by implementing blended learning. There are three things that must be prepared in the implementation of blended learning, namely curriculum design, teaching strategies and integration of technology application (Garrison \& Vaughan, 2012). Curriculum design is related to the elaboration of subject matter into topics that must be taught to achieve learning objectives in accordance with specified competencies. At the same time also prepared teaching strategies that will be applied by teachers when delivering material in class. Also consider the use of technology that can help the learning process, as well as to provide alternative learning and independence for students in learning.

To increase the strength and success of the implementation of blended learning in the learning process, there are 5 (five) things that must be considered in preparing the model (Bailey et al., 2013). These five things relate to student interactions, that is with other students, lecturers, communities, teaching materials, and technology. In preparing this learning model with blended learning, the five interactions must be possible to be applied to the learning process. The learning process is no longer the responsibility of a lecturer alone, but rather a shared responsibility, especially by students. However, the roles and tasks of lecturers become even greater, because they are required to be able to create an atmosphere and environment of an interesting learning process and give an active role to students. The implementation of the blended learning model and the interactions expected to occur from this learning process can be illustrated in Figure 2.

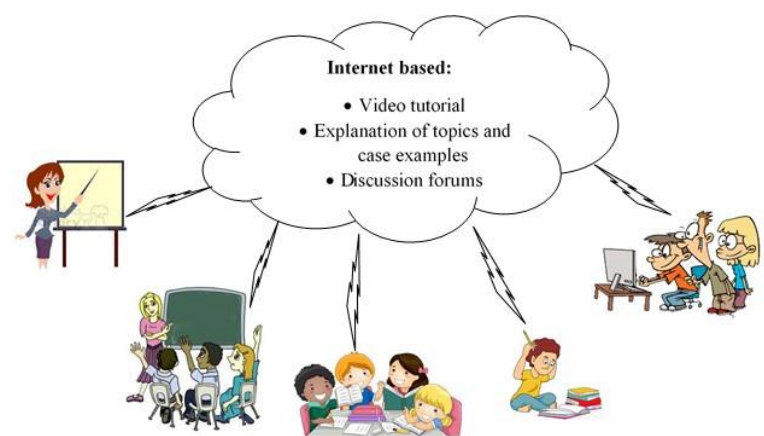

Figure 2. Interaction and blended learning implementation model

By increasing the question and answer session or discussion, the interaction between students and lecturers can be built properly. Interaction can be initiated by lecturers by asking questions to students during lectures or giving students the opportunity to ask questions. When there are students who ask questions, it's a good idea for lecturers to give other students the opportunity to try to answer first. Or the lecturer gives the opportunity for students to discuss

Karma, I. G. M., Darma, I. K., \& Santiana, I. M. A. (2019). Teaching strategies and technology integration in developing blended learning of applied mathematics subject. International Research Journal of Engineering, IT \& Scientific Research, 5(5), 16-25. https://doi.org/10.21744/irjeis.v5n5.726 
the answers to the questions given. In this situation interaction has been created between students and lecturers and students and other students. Learning strategies that are suitable for this case are concept learning, problem-solving and case discussion.

To provide more understanding or repetition of learning independently, the learning process can be complemented with video tutorials and discussion of material and case examples. In the past, video tutorials were common in the campus library. Likewise with textbooks and case practice questions, though of course they can also be owned by students themselves. With the development of technology, especially the Internet, all of this material can be provided online. Students can access it anytime, anywhere, according to the conditions. With existing technology, it is also possible to form an online discussion forum. This forum can be used for mutual discussion, questions, and answers on certain issues for certain communities.

Applied Mathematics courses in the Department of Mechanical Engineering Politeknik Negeri Bali consists of 2 levels, namely Applied Mathematics I and II which are taught in semester 1 and semester 2. The expected learning outcomes of this course are able and skillful using concepts, mathematical knowledge as a foundation to analyze, formulate and solve mathematical problems that arise both in the field of mechanical engineering and in everyday life. These learning outcomes are further translated into a number of expected final abilities, which must be achieved by students. Each final ability is associated with a number of topics/materials that will be studied during 16 meetings in one semester, including the midterm and final exams.

Table 1

Topic, teaching strategies and technology integration on applied mathematics subject I

\begin{tabular}{|c|c|c|c|}
\hline Week & Topic & Teaching Strategies & Technology Integration \\
\hline $1-2$ & $\begin{array}{l}\text { Intoduction to Application } \\
\text { Software }\end{array}$ & $\begin{array}{l}\text { - Demo program } \\
\text { - Case study } \\
\text { simulation }\end{array}$ & $\begin{array}{l}\text { Application software operation } \\
\text { tutorial video }\end{array}$ \\
\hline 3 & $\begin{array}{l}\text { Real number systems: powers, } \\
\text { roots, and logarithms }\end{array}$ & $\begin{array}{l}\text { - Understanding of } \\
\text { concepts } \\
\text { - Problem-based } \\
\text { learning } \\
\text { - Solution to problem } \\
\text { - Case discussion }\end{array}$ & $\begin{array}{l}\text { - Video tutorial on real number } \\
\text { operations } \\
\text { - Video tutorial on power rule } \\
\text { - Video tutorial on roots } \\
\text { - Video tutorial on logarithms } \\
\text { - Explanation of topics and case } \\
\text { examples online } \\
\text { - Online discussion forums }\end{array}$ \\
\hline $4-6$ & Equations & $\begin{array}{l}\text { - Understanding of } \\
\text { concepts } \\
\text { - Solution to problem } \\
\text { - Case discussion }\end{array}$ & $\begin{array}{l}\text { - Explanation of topics and case } \\
\text { examples online } \\
\text { - Online discussion forums }\end{array}$ \\
\hline $7-8$ & Relation and Function & $\begin{array}{l}\text { - Understanding of } \\
\text { concepts } \\
\text { - Solution to problem } \\
\text { - Case discussion }\end{array}$ & $\begin{array}{l}\text { - Video tutorial on relation and } \\
\text { function } \\
\text { - Explanation of topics and case } \\
\text { examples online } \\
\text { - Online discussion forums }\end{array}$ \\
\hline 9 & Midterm Exam & & \\
\hline $10-12$ & Fundamentals of geometry & $\begin{array}{l}\text { - Understanding of } \\
\text { concepts } \\
\text { - Case discussion }\end{array}$ & $\begin{array}{l}\text { - Video tutorial on the } \\
\text { fundamentals of geometry } \\
\text { - Explanation of topics and case } \\
\text { examples online } \\
\text { - Online discussion forums }\end{array}$ \\
\hline 13 & Geometry & $\begin{array}{l}\text { - Understanding of } \\
\text { concepts } \\
\text { - Case discussion }\end{array}$ & $\begin{array}{l}\text { - Video tutorial on geometry } \\
\text { - Explanation of topics and case } \\
\text { examples online } \\
\text { - Online discussion forums }\end{array}$ \\
\hline $14-15$ & Trigonometric basics, sine and & - Understanding of & - Video tutorial on trigonometric \\
\hline
\end{tabular}




\begin{tabular}{llll}
\hline & cosine rules, trigonometric & concepts & $\bullet$ Explanation of topics and case \\
equations, graphs of trigonometric & $\bullet$ Solution to problem & examples online \\
functions & - Case discussion & $\bullet$ Online discussion forums \\
16 & Final Exam & & \\
\hline
\end{tabular}

Table 2

Topic, Teaching Strategies and Technology Integration on Applied Mathematics Subject II

\begin{tabular}{|c|c|c|c|}
\hline Week & Topic & Teaching Strategies & Technology Integration \\
\hline $1-2$ & Limit and Continuity & $\begin{array}{l}\text { - Understanding of } \\
\text { concepts } \\
\text { - Solution to problem } \\
\text { - Case discussion }\end{array}$ & $\begin{array}{l}\text { - Explanation of topics and case } \\
\text { examples online } \\
\text { - Online discussion forums }\end{array}$ \\
\hline $3-6$ & $\begin{array}{l}\text { Differential and derivative } \\
\text { functions of algebra }\end{array}$ & $\begin{array}{l}\text { - Understanding of } \\
\text { concepts } \\
\text { - Problem-based } \\
\text { learning } \\
\text { - Solution to problem } \\
\text { - Case discussion }\end{array}$ & $\begin{array}{l}\text { - Video tutorial on differential and } \\
\text { derivative functions } \\
\text { - Explanation of topics and case } \\
\text { examples online } \\
\text { - Online discussion forums }\end{array}$ \\
\hline $7-9$ & Partial Differential & $\begin{array}{l}\text { - Understanding of } \\
\text { concepts } \\
\text { - Problem-based } \\
\text { learning } \\
\text { - Solution to problem } \\
\text { - Case discussion }\end{array}$ & $\begin{array}{l}\text { - Video tutorial on partial } \\
\text { differential } \\
\text { - Explanation of topics and case } \\
\text { examples online } \\
\text { - Online discussion forums }\end{array}$ \\
\hline 10 & Midterm Exam & & \\
\hline $11-13$ & Integral & $\begin{array}{l}\text { - Understanding of } \\
\text { concepts } \\
\text { - Problem-based } \\
\text { learning } \\
\text { - Solution to problem } \\
\text { - Case discussion }\end{array}$ & $\begin{array}{l}\text { - Explanation of topics and case } \\
\text { examples online } \\
\text { - Online discussion forums }\end{array}$ \\
\hline $14-15$ & Definite Integral & $\begin{array}{l}\text { - Understanding of } \\
\text { concepts } \\
\text { - Problem-based } \\
\text { learning } \\
\text { - Solution to problem } \\
\text { - Case discussion }\end{array}$ & $\begin{array}{l}\text { - Explanation of topics and case } \\
\text { examples online } \\
\text { - Online discussion forums }\end{array}$ \\
\hline 16 & Final Exam & & \\
\hline
\end{tabular}

Tables 1 and 2 show that concept understanding, problem-based learning, problem-solving and case discussion are dominant learning strategies applied to learn applied mathematics. This strategy is commonly applied in traditional face-to-face learning but is felt to be unable to reach the learning objectives to the maximum. To improve learning outcomes, blended learning is implemented by integrating traditional face-to-face learning with technology-based learning, specifically the Internet and multimedia. This integrated learning consists of offline and online learning. Offline learning is done traditionally in the classroom, while online learning is done by utilizing the Internet, so it can be accessed anywhere and anytime. This online learning consists of video tutorials, discussion of material and case examples, and discussion forums. In addition to the material that can be prepared by the lecturer, this online material can also be linked to existing material related links.

No matter how good and perfect the learning process has been prepared, in the end, the key to success lies entirely in the students themselves. Students are required to be active and independent. The role of the lecturer is

Karma, I. G. M., Darma, I. K., \& Santiana, I. M. A. (2019). Teaching strategies and technology integration in developing blended learning of applied mathematics subject. International Research Journal of Engineering, IT \& Scientific Research, 5(5), 16-25. https://doi.org/10.21744/irjeis.v5n5.726 
simply to ensure that the objectives of the learning process are well achieved. Evaluation and monitoring must always be carried out, both in the process and in learning outcomes.

\section{Conclusion}

The learning process of Applied Mathematics in the Mechanical Engineering Study Program in Politeknik Negeri Bali is generally required to be able to provide an understanding of various concepts according to the topics taught, able to solve various related problems and at the same time be able to apply in various technical problems in the engineering field. Repeated learning is needed and is equipped with various case examples and discussion. The blended learning model is very suitable to be applied, by integrating traditional face-to-face learning with multimedia and online-based learning. To gain excellence and innovation from this blended learning, planning, consideration, and integration of curriculum designs are needed in relation to the topic that must be taught, learning strategies that are appropriate to the topic, and integrating it with existing technology, especially the Internet.

\section{Conflict of interest statement}

The authors declared that they have no competing interest.

Statement of authorship

The authors have a responsibility for the conception and design of the study. The authors have approved the final article.

\section{Acknowledgments}

The author would like to thank The Directorate Research and Social Service, Ministry of Research, Technology, and Higher Education for their financial support that this research was successfully undertaken. 


\section{References}

Alkhalaf, S., Drew, S., AlGhamdi, R., \& Alfarraj, O. (2012). E-learning system on higher education institutions in KSA: Attitudes and perceptions of faculty members. Procedia-Social and Behavioral Sciences, 47, 1199-1205. https://doi.org/10.1016/j.sbspro.2012.06.800

Alonso, F., López, G., Manrique, D., \& Viñes, J. M. (2005). An instructional model for web-based e-learning education with a blended learning process approach. British Journal of educational technology, 36(2), $217-235$. https://doi.org/10.1111/j.1467-8535.2005.00454.x

Alonso, F., López, G., Manrique, D., \& Viñes, J. M. (2005). An instructional model for web-based e-learning education with a blended learning process approach. British Journal of educational technology, 36(2), 217-235. https://doi.org/doi: 10.1111/j.1467-8535.2005.00454.x

Altbach, P. G., \& Knight, J. (2007). The internationalization of higher education: Motivations and realities. Journal of studies in international education, 11(3-4), 290-305. https://doi.org/10.1177\%2F1028315307303542

Azizan, F. Z. (2010). Blended learning in higher education institution in Malaysia. In Proceedings of regional conference on knowledge integration in ICT (Vol. 2010, pp. 454-466).

Bailey, J., Martin, N., Schneider, C., Vander Ark, T., Duty, L., Ellis, S., ... \& Terman, A. (2013). Blended learning implementation guide 2.0. DIGITAL SHIFT.

Bower, M., Dalgarno, B., Kennedy, G. E., Lee, M. J., \& Kenney, J. (2015). Design and implementation factors in blended synchronous learning environments: Outcomes from a cross-case analysis. Computers \& Education, 86, 1-17. https://doi.org/10.1016/j.compedu.2015.03.006

Cohen, D. (1998). Chronicle of Higher Education. The Women's Review of Books, 15(5), 27-27.

Czerkawski, B. C., \& Lyman, E. W. (2016). An instructional design framework for fostering student engagement in online learning environments. TechTrends, 60(6), 532-539.

Ellis, R., \& Goodyear, P. (2013). Students' experiences of e-learning in higher education: the ecology of sustainable innovation. Routledge. https://doi.org/10.4324/9780203872970

Evans, C. (2008). The effectiveness of m-learning in the form of podcast revision lectures in higher education. Computers \& education, 50(2), 491-498. https://doi.org/10.1016/j.compedu.2007.09.016

Friesen, N. (2012). Report: Defining blended learning. Learning Space.

Garrison, D. R., \& Vaughan, N. D. (2008). Blended learning in higher education: Framework, principles, and guidelines. John Wiley \& Sons.

George-Walker, L. D., \& Keeffe, M. (2010). Self-determined blended learning: a case study of blended learning design. Higher Education Research \& Development, 29(1), 1-13. https://doi.org/10.1080/07294360903277380

Ginaya, G., Rejeki, I. N. M., \& Astuti, N. N. S. (2018). The effects of blended learning to students' speaking ability. International Journal of Linguistics, Literature and Culture, 4(3), 1-14.

Graham, C. R. (2011). Blended Learning Models. In Encyclopedia of Information Science and Technology, Second Edition. https://doi.org/10.4018/978-1-60566-026-4.ch063

Graham, C. R., \& Dziuban, C. D. (2008). Blended Learning Environments. Handbook of Research on Educational Communications and Technology. https://doi.org/10.1080/02652030701883203

Hoic-Bozic, N., Mornar, V., \& Boticki, I. (2008). A blended learning approach to course design and implementation. IEEE transactions on education, 52(1), 19-30.

Johnson, S. D., \& Aragon, S. R. (2003). An instructional strategy framework for online learning environments. New directions for adult and continuing education, 2003(100), 31-43. https://doi.org/10.1002/ace.117

Kiviniemi, M. T. (2014). Effects of a blended learning approach on student outcomes in a graduate-level public health course. BMC medical education, 14(1), 47.

Laurillard, D. (2005). E-learning in higher education. In Changing higher education (pp. 87-100). Routledge.

Mahayukti, G. A., Gita, I. N., Suarsana, I. M., \& Hartawan, I. G. N. Y. (2017). The effectiveness of self-assessment toward understanding the mathematics concept of junior school students. International Research Journal of Engineering, IT \& Scientific Research, 3(6), 116-124.

Mahendra, I. W. E. (2016). Contextual learning approach and performance assessment in mathematics learning. International Research Journal of Management, IT and Social Sciences, 3(3), 7-15.

Moskal, P., Dziuban, C., \& Hartman, J. (2013). Blended learning: A dangerous idea?. The Internet and Higher Education, 18, 15-23. https://doi.org/10.1016/j.iheduc.2012.12.001

Ozkan, S., \& Koseler, R. (2009). Multi-dimensional students' evaluation of e-learning systems in the higher education context: An empirical investigation. Computers \& Education, 53(4), 1285-1296. https://doi.org/10.1016/j.compedu.2009.06.011

Karma, I. G. M., Darma, I. K., \& Santiana, I. M. A. (2019). Teaching strategies and technology integration in developing blended learning of applied mathematics subject. International Research Journal of Engineering, IT \& Scientific Research, 5(5), 16-25. https://doi.org/10.21744/irjeis.v5n5.726 
Pande, D., Wadhai, V. M., \& Thakare, V. M. (2016). E-learning system and higher education. International Journal of Computer Science and Mobile Computing, 5(2), 274-280.

Pina, AB (2004). Blended learning. Basic concepts. Pixel-Bit Media and education magazine , (23), 7-20.

Porter, W. W., Graham, C. R., Spring, K. A., \& Welch, K. R. (2014). Blended learning in higher education: Institutional adoption and implementation. Computers \& Education, 75, 185-195. https://doi.org/10.1016/j.compedu.2014.02.011

Rennie, F., \& Morrison, T. (2013). E-learning and social networking handbook: Resources for higher education. Routledge. https://doi.org/10.4324/9780203120279

Samarawickrema, G., \& Stacey, E. (2007). Adopting Web-Based Learning and Teaching: A case study in higher education. Distance education, 28(3), 313-333. https://doi.org/10.1080/01587910701611344

Sanchez, S. M. M., \& Garcia, E. K. M. (2019). Human resource development in Faculty of Physical and Chemical Mathematical Sciences. International Journal of Social Sciences and Humanities,3(1), 1-6. https://doi.org/10.29332/ijssh.v3n1.242

Sife, A., Lwoga, E., \& Sanga, C. (2007). New technologies for teaching and learning: Challenges for higher learning institutions in developing countries. International journal of education and development using ICT, 3(2), 57-67.

Singh, H. (2003). Building effective blended learning programs. Educational Technology-Saddle Brook Then Englewood Cliffs NJ-, 43(6), 51-54.

Stockwell, B. R., Stockwell, M. S., Cennamo, M., \& Jiang, E. (2015). Blended learning improves science education. Cell, 162(5), 933-936. https://doi.org/10.1016/j.cell.2015.08.009

Subramanian, R. M. (2016). The role of e-learning, the advantages and disadvantages of its adoption in Higher Education. Tamilnadu.

Sun, P. C., Tsai, R. J., Finger, G., Chen, Y. Y., \& Yeh, D. (2008). What drives a successful e-Learning? An empirical investigation of the critical factors influencing learner satisfaction. Computers \& education, 50(4), 1183-1202. https://doi.org/10.1016/j.compedu.2006.11.007

Suweken, G., Waluyo, D., \& Okassandiari, N. L. (2017). The improvement of students' conceptual understanding and students' academic language of mathematics through the implementation of SIOP model. International Research Journal of Management, IT and Social Sciences, 4(4), 58-69.

Tambunan, L., Rusdi, R., \& Miarsyah, M. (2018). Efectiveness of Problem Based Learning Models by Using ELearning and Learning Motivation Toward Students Learning Outcomes on Subject Circullation Systems. Indonesian Journal of Science and Education, 2(1), 96-104.

Thorne, K. (2003). Blended learning: how to integrate online \& traditional learning. Kogan Page Publishers.

Tyley, S. (2012). Blended learning. Fire Risk Management.

Widana, I. W., Parwata, I. M. Y., Parmithi, N. N., Jayantika, I. G. A. T., Sukendra, K., \& Sumandya, I. W. (2018). Higher order thinking skills assessment towards critical thinking on mathematics lesson. International Journal of Social Sciences and Humanities, 2(1), 24-32. https://doi.org/10.29332/ijssh.v2n1.74

Wu, J. H., Tennyson, R. D., \& Hsia, T. L. (2010). A study of student satisfaction in a blended e-learning system environment. Computers \& Education, 55(1), 155-164. https://doi.org/10.1016/j.compedu.2009.12.012 


\section{Biography of Authors}

\begin{tabular}{|c|c|}
\hline (2) & $\begin{array}{l}\text { I Gede Made Karma, } \\
\text { Master in Information Technology from Institut Teknologi Bandung. Interested and } \\
\text { have expertise in the field of system development and programming. Develop a number } \\
\text { of accounting information systems for a number of companies. Currently active in } \\
\text { developing systems for travel agency companies. Associate Professor in computer } \\
\text { applications in the Accounting Department at Politeknik Negeri Bali, Badung, Bali, } \\
\text { Indonesia. } \\
\text { Email: igmkarma@pnb.ac.id }\end{array}$ \\
\hline & $\begin{array}{l}\text { I Ketut Darma, } \\
\text { Finishing elementary school in SD } 2 \text { Beraban 1971, a junior high school in Cipta Karya } \\
\text { Pejaten. in 1974, School of Medium Technology Saraswati Denpasar in 1979, graduate } \\
\text { of University of Mahasaraswati Denpasar Faculty of Teacher Training and Education } \\
\text { majoring in Mathematics education 1986, and graduate of Singaraja Ganesha } \\
\text { education university in } 2004 \text { on Educational Research and Evaluation study program } \\
\text { and he is now a doctor of education. } \\
\text { Email: ketutdarma@pnb.ac.id }\end{array}$ \\
\hline & $\begin{array}{l}\text { I Made Anom Santiana, } \\
\text { Completed a master's degree in Work Ergonomics from the Udayana University. Active } \\
\text { in research and development of ergonomic-friendly equipment to improve comfort, } \\
\text { health and work productivity. Teaching courses in Occupational Safety and Health, } \\
\text { Applied Physics, Applied Mathematics, and Engineering Statistics at the Department of } \\
\text { Civil Engineering, Politeknik Negeri Bali, Badung, Bali, Indonesia. } \\
\text { Email: madeanoms@yahoo.co.id }\end{array}$ \\
\hline
\end{tabular}

Karma, I. G. M., Darma, I. K., \& Santiana, I. M. A. (2019). Teaching strategies and technology integration in developing blended learning of applied mathematics subject. International Research Journal of Engineering, IT \& Scientific Research, 5(5), 16-25. https://doi.org/10.21744/irjeis.v5n5.726 